DOI: $10.31866 / 2410-1915.21 .2020 .208242$

UDC 316.346.2-055.2:392(477)

\title{
A WOMAN IN THE UKRAINIAN RITUALS OF THE WINTER CALENDAR CYCLE
}

\author{
Olena Lyniuk
}

PhD in Cultural Studies, Associate Professor, ORCID:0000-0003-0665-9589,partyzone5@ukr.net, Kyiv Municipal Academy of Circus and Variety Arts, 86, Zhylianska St., Kyiv, 02000, Ukraine

\section{For citations:}

Lyniuk, O. (2020). A Woman in the Ukrainian Rituals of the Winter Calendar Cycle. Culture and Arts in the Modern World, 21, 131-147. https://doi.org/10.31866/2410-1915.21.2020.208242.

The purpose of the article is to identify gender priorities (parity of male and female roles) in the Ukrainian rites of the winter calendar cycle based on the analysis of the mythological origins of the rite system and the composition of the rites, the main role in the performance of which belonged to a woman. To achieve this goal, the following methods were used: generalization - for the systematization of the scientific sources; analytical method - for the analysis of the cause-and-effect features, the emergence and formation of the trends in the complex study of the scientific issues; the method of the retrospective reconstruction or historical and genetic method, which is based on the idea that the initial stages of the development of certain objects and phenomena can be reproduced on the basis of the later stages. The scientific novelty of the study is to analyze the peculiarities of the distribution of female and male roles, identify and justify the special role of a woman and emphasize the gender priorities in the rites of the winter calendar cycle. Conclusions. The study demonstrates that the cult of Mother Earth, Mother Water defines the essential role of the feminine principle both in the macrocosm environment of gods and elemental spirits, and in the microcosm of the family, determining the corresponding gender priorities of the rituals. It has been defined that the role of a women in the winter rites differs from the role of a man in its symbolic content, but it is devoid of any signs of hierarchical subordination, secondary importance. Sometimes, even the opposite - it is the leading one, which is explained by the mythological content of Christmas and New Year rites as those that are addressed directly to the highest female deity and indicate the organic and deep connection of a woman with the goddesses of Earth and Water. This suggests that the image of a woman in the traditional Ukrainian culture was to a certain extent perceived as the everyday embodiment of these sacred entities and is a confirmation of the relations of ritual and myth. It was revealed that the belief in the supremacy of the female deity was transformed under the influence of Christianity. The gender hierarchy of the traditional Ukrainian family mainly depends not so much on the established patriarchal rules, but on the personality and its social status. The gender identity of the Ukrainian rites of the winter calendar cycle consists in the 
parity of female and male roles, which symbolizes the harmony in the family microcosm and the macrocosm of the environment.

Keywords: mythology; folk calendar; Mother Water; Mother Earth; Mokosh; micro-, macrocosm; parity.

\section{Introduction}

Gender asymmetry is believed to exist in all societies and cultures, although specific ideas of the social functions of men and women in societies are not the same. Determining the woman's social status in the contemporary world is the issue of current importance, without which further progress of science and humanity is impossible, and which is the litmus of the society's development. Ukrainian women are an active factor in the ethnocultural self-reproduction of the nation, they represent and translate the traditional ethnoculture. Research on traditional ritual culture form a reliable conceptual foundation for the woman's status in the Ukrainian society. The role of a woman in the calendar rituals of Ukrainians has become the subject of the special research by the Ukrainian ethnologists, folklorists, and culturologists, but the thesis of the leading role of a man in the rites of the winter cycle is well-established. The analysis of gender aspects of the Ukrainian winter calendar rites allows us to question the traditional for the ethnographic sources statement that the leading role in the rites of the winter cycle belongs to a man.

Calendar rites of Ukrainians are considered in the research of ethnographers, folklorists, historians of the second half of the 19th - early 20th century. Some gender aspects of the Ukrainian rites were studied by K. Hrushevska (2012). The author analyses the household magic of the Ukrainian women and the associated belief in the active magical power of the female body. In the scientific study devoted to Slavic pagan holidays, M. Kostomarov (2014) describes their celebration of a female mythological being in the symbolic image of Lada and Zhyva, and considers the rites' mythology and symbolism as ideas formed in a result of every day needs. The work of M. Maksymovych (2002) has a special research character and represents folk life and its customs. Calendar rites are considered in the methodological and philosophical fundamental works of the outstanding historian M. Hrushevskyi (1993), who emphasized the special role in the archaic consciousness of Ukrainians of the rites of the calendar cycle of their pagan basis, ritual poetry and their secularization, transformation due to the pressure of the Christian religion. Rites of the calendar cycle were considered by the Soviet and post-Soviet ethnologists - V. Voitovych (2005), using a broad scientific source base, provided the folk heroes of Slavic mythology with original characteristics of spirits, gods, demonic characters. The register of V. Zhaivoronok's (2006) dictionary and reference book, based on the encyclopaedic and scientific materials, contains mythological, religious, historical names that are closely related to the primitive religious world-view of the Ukrainian people and the traditions of ritual culture. The work of the famous Russian art critic O. Kurochkin (2014) highlights the history of the calendar holidays, in which the author gives much attention to the main milestones of 
the annual circle, the special feature of the celebration. V. Skurativskyi (1994) fully described calendar customs and beliefs, presented interesting information on everyday life, folk crafts, legends, proverbs, folk aphorisms, etc.

Studies of ethnologists and culturologists of the diaspora D. Antonovych (1993), O. Voropai (1993), S. Kylymnyk (1994) summarized and provided a detailed description of the rites of the calendar cycle, but without focusing on the gender aspect of the rites performance.

Modern cultural studies by M. Hrymych (2012) quite fully represented the role of a woman in the calendar rites and traditional Ukrainian society. Among the works concerning the traditional role of women in the ceremonial activities, the work of N. Hromova (2012) is valuable. The author highlights the range of functions that women performed in the calendar rite. O. Kis (2012) analyses the content and structure of the Ukrainian ethno-cultural stereotype of femininity, the idea of female traits of behaviour, personality, appearance and critically rethinks the idealized image of a woman.

However, researchers, focusing on the essence of the rite, rarely notice the important thing - who has the main role in the performance of its magical protective actions - a woman or a man, and the magical meaning of these rites. Analysis of the distribution of roles, the comparison of their symbolic meaning, gives grounds to assume complementarity, parity roles of men and women in performing the ritual as to their maximum efficiency and effectiveness for the needs of everyday life and at the same time to question the usual assertion that a man has the leading role in the winter cycle rituals.

\section{Purpose of the article}

The purpose of the article is to identify gender priorities (parity of male and female roles) in the Ukrainian rites of the winter calendar cycle based on the analysis of the mythological origins of the rite system, the main female mythologies and the quantitative composition of the rites, the main role in the performance of which belonged to a woman.

To achieve this goal, the following methods were used: generalization - for systematization of the scientific sources; analytical method - for analysis of the cause-and-effect features, the emergence and formation of the trends in the complex study of the scientific issues; method of the retrospective reconstruction or historical and genetic method, which is based on the idea that the initial stages of the development of certain objects and phenomena can be reproduced on the basis of the later stages.

\section{Main research material}

Rites of the calendar cycle are the basis of the Ukrainian ritual culture, since they record the routine of life of an individual and society during the year in an inseparable, organic connection with nature's seasons. As noted by A. Ponomarov (Ponomarov et al., 1991), staginess of the human activity in the traditional culture was divided into three phases: 
- wedding season, when people got married;

- period of harvesting products for the winter;

- time to honour the ancestral cult.

"These three moments concentrated in themselves the trinity of the most important components of the human life: physical existence, procreation and spiritual reproduction. The calendar rite has the same logical connection with the nature, dividing in accordance with seasons into four parts: winter, spring, summer and autumn. Each cycle of rites was timed, on the one hand, to natural phenomena, on the other - to the corresponding types of the agricultural activities" (Popovych, 2001, p. 631).

Noting the multifunctionality of the national agricultural calendar, M. Hrushevskyi (1993) defined it as "our only religious system”: “...There were no shrines, no temples, no sacred space, no generally recognized places of holy services. The annual calendar circle is at the same time characteristic of our unified religious system, incomplete, not unified in any ideological integrity, prematurely broken and destroyed by new church events" (p. 171).

The pre-Christian religions of the Indo-European peoples inherited the pantheon of the ancient Indo-European gods. The main deities of the Indo-Europeans were the father-God (ancient Indian Dyaus Pitr, Greek Zeus Pater, Lithuanian Perkunas, Slavic Perun), who is associated with the sky, and the mother-Goddess (Greek Demetra, Slavic Mother-Raw-Earth or Earth-Mother). According to the chronicle, Mokosh was the only deity who personified the female principle among statues of other gods erected by Vladymyr the Great. "And he put idols on the hill, outside the dark courtyard: Perun wooden, - and his head [was] silver, and his mustache - gold, - and Khors, and Dazhboh, and Stryboh, and Symarhl, and Mokosh. And people sacrificed to them, calling them gods...” (Myshanych, 1989). The general Slavic character of Mokosh is indicated by the Slovenian fairy tale about the enchantress Mokoska, West Slavic toponyms such as Mokosin verh ("Mokoshyn Verkh"), the Polabian Mukes, the old-Lusatian Mococize, and others. "Typologically, Mokosh is close to the Greek Moirai, German Norns, which spin the threads of fate, the Hittite goddess of the underworld, the Iranian Apgbucipe Anaxime (comparison of Mother-Raw-Earth), etc. and continues the ancient image of the female deity - the wife (or female correspondence) of the Thunderer Perun in the Slavic mythology" (Meletinskii, 1991).

The memory of this female deity was preserved in Ukraine until the middle of the $19^{\text {th }}$ century. A peculiar transformation of Mokosh after the adoption of Christianity was Paraskeva Piatnytsia (Paraskeva Friday), which in the Ukrainian rituals of the 19th century appears as a loose haired woman, who was led through Ukrainian villages. Piatnytsia received offerings of yarn and flax thrown into a well. Mokosh's image semantics is differently interpreted in the Ukrainian ethnology. So, V. Voitovych (2005) pays attention to Mokosh's characteristic features that are not mentioned by other authors. "Mokosh - the great goddess of mercy, female endeavours and skills, fertility and life-giving female power. Mokosh is an intermediary between heaven and earth, and therefore on spring ritual towels, she was always depicted with her hands raised to the sky, to the source of heat and humidity - unlike the summer ritual towels, 
where the hands are lowered to the land, which gave the birth to grain that is ready for the new harvest. Mokosh is the patroness of rains and related spring rites, the patroness of childbirth and the patroness of women in labour. The symbol of the goddess is a spinning-wheel and a spindle" (p. 117).

The name of Mokosh is mentioned next to the vila-mermaids in almost all texts of the preaching literature of the $11^{\text {th }}-14^{\text {th }}$ centuries, and in the "Word of Saint Gregory" (12 $2^{\text {th }}$ century) Mokosh is named even before Perun in the list of the most dangerous idols for Orthodox. According to V. Skurativskyi (1987), in the pantheon of Vladymyr's gods, Mokosh took over the functions of the ancient berehynias: "By erecting the sculpture of Mokosh in his pantheon, the Prince obviously intended to give it all the spiritual guardianship inherent in the female goddesses - berehynias. In addition to home crafts (weaving, embroidery, Easter painting crafts), the protection of wells and springs, the generosity of crops, as well as the preservation of the home, the blessing and protection of the Prince and his wife, when they went on a campaign, fell under the power of Mokosh" (p. 39).

Researchers of pre-Christian beliefs, as a rule, do not distinguish the function of Mokosh, defined by V. Skurativskyi (1987) as "a blessing to the Prince and his wife", although it was significant and, perhaps, defining in the context of Vladymyr's pantheon of gods. It is quite possible that this function, programmed as a defining one, did not develop due to the Christianization of the Prince and his wife and was erased from the people's memory. An attempt made by V. Skurativskyi (1987) to reconstruct the historical transformations of the functions of Mokosh (originally - the goddess of fertility, later - Berehynia) is rational, but not exhaustive. The analysis of the above sources shows that there is no consensus in the research interpretation of the image of Mokosh. Definitions of the status, role and functions of the goddess range from recognizing her as the supreme female deity on the grounds that the idol of Mokosh was placed in the Vladymyr's pantheon of gods, to the denial of her belonging to Slavic mythology. Thus, describing the pre-Christian religion of the ancestors, D. Antonovych (1993) states: “...we cannot speak with certainty about any genealogy of pre-Christian gods. Even all the gods that are named in literary sources are all male; there are no goddesses at all; it is possible that the goddess was some obscure "Mokosh", but it is possible that she was the deity of some Finnish tribe under the Kyivan state" (p. 195). However, it should be argued that the pantheon, described in the Kyiv chronicle, being associated with the princely ruling ideology, did not reflect the real priorities of popular beliefs, which were dominated not by male principle, but by female one. Probably, Mokosh is only a partial personification of the Great Mother Goddess, whose image was strongly associated in the beliefs of the agrarian people with the land. "Mother-raw-Earth" - the goddess of the earth, which did not have a clear anthropomorphic embodiment", notes V. Voitovych (Voitovych, 2005, p. 294) and, at the same time, interprets the image of the earth as "a symbol of the feminine principle, motherhood", as the embodiment of "the progenitor and Mother Earth of all living creatures" (p. 188). The land was revered and worshiped. It gives everything necessary for life and takes along after death. Being in constant eco- 
nomic, practical and ritual communication with the land, the people of agrarian culture represented it as a personified being that has a direct bearing on prosperity, health, life, and peace in the real and the other world. "They prayed to the land in pre-Christian and Christian times, swore by the land, bless with the name of the land ("be rich as the land") and cursed ("may the land swallow you up", "may the holy land not accept you”) (Zhaivoronok, 2006, p. 243). Naturally, a number of special calendar holidays were dedicated to the land, among which researchers distinguish "The day of the spirits", when the land has a "birthday", and the land holiday from the Entry to the Annunciation day.

The Great Mother Goddess in Slavic, particularly Ukrainian mythology, is omnipresent and diverse. The heavenly hypostasis of the Great Mother Goddess partially embodies the sun, because the comparison of a woman with the sun is constantly present in the Ukrainian ritual songs of the praising character, in particular, in carols. Her earthly hypostasis is embodied by the image of Mother-Raw-Earth. Obviously, Mokosh is really the connecting link between heavens and earth in the female format - "the Queen of water", whose symbol on sacred household items - embroidered towels - is often the world tree. "... the Woman-goddess is either replaced by a tree, or looks like a tree, - notes M. Popovych (2001) and makes a conclusion that is important in the context of this study: - Likeness of the female character of the Slavic pantheon to the world tree means that the Mother Goddess had the function of organising the Universe; this is emphasized by her ritual text” (p. 41).

The functions of ordering the macro- and microcosm inherent in the Mother Goddess were powerfully manifested in the formation of the Ukrainian national calendar, largely determining the role of a woman in the calendar rites. Except for the Great Mother - the progenitor of all life creatures and the one who put the world in order - Mokosh, in the pantheon of Slavic gods, which has not been finalized and was badly affected by time, there are also lower female deities Lada, Mara, Zhyva, Rozhanytsa and others. The memory of these characters is partially preserved in the calendar interpretation of the related myths. In general, it should be recognized that the form of rites is often more stable than their content. This determines the layering and transformation of the meanings while preserving the form of a particular rite.

In calendar ritual mythological, sacred and practical, economic aspects are organically combined. The dominance of practical, everyday aspects is also typical to the later forms of the national calendar, modified under the influence of Orthodoxy. "This led to the fact that for a Ukrainian peasant the annual cycle of holidays was not so much the celebration of any Christian saints or a way of commemorating certain events in Christian history, but a kind of a reference point for housekeeping, preparing or conducting any type of agricultural work" (Zhulynskyi, 2003, pp. 46-47). The national calendar in its "pure" pre-Christian form has not been preserved - "at every step we must take into account not only the devastation and destruction, but also the changes, interruptions and transfers caused by the Church and the Church calendar in the old system" (Hrushevskyi, 1993, p. 171). The Orthodox clergy consistently fought against national holidays, associating them with the Christian holidays or prohibiting 
them in order to eradicate the naturalistic world-view of the people and replace it with the Christian one. The final formalization of the popular Christianity of Ukrainians, which A. Kolodnyi considers as a mass level of popular culture, took place in the 18th century (Zhulynskyi, 2003, p. 62). The peculiarity of the Ukrainian religiosity was manifested in the creation of a kind of Trinity of Jesus Christ, the Mother of God and St. Nicholas "with the preference of the Mother of God as the queen of Ukraine" (Zhulynskyi, 2003, p. 62). "This perception of the Christian dogma is due to a certain utilitarian and selective approach. This is the hope for protection and compensation for earthly hardships (the mission of Jesus Christ), the consecration of the family hearth and the place of a woman in it (the patronage of the Virgin Mary), the search for a force that would help a person in his life activities, in particular in the practical one (the example of life and help of Saint Nicholas)" (Zhulynskyi, 2003, p. 62). The traditional faith of the people of the agrarian culture left unchanged the primacy of the female deity, but under the powerful influence of the prevailing Christian dogma, it determined the specifics of gender dominants in the national calendar.

Christian doctrine, without explaining the problems of everyday life, the environment and practical activity, could not satisfy the spiritual needs of the peasant, who turned to the traditional wisdom of the ancestors, honouring the cults of the old gods, which were largely formally replaced by Christian saints with the same functions.

The Holy family and saints in the Ukrainian carols act as sowers and ploughmen, and their roles in the work process are distributed in accordance with the established roles in the peasant life: Saint Nicholas follows the plough, and Saint Michael drives oxen, Mother of God (master's wife, mother) carries food, God (master) sows, the Son of God works the land. Thus, the cult of land and agricultural labour is the basis of the world-view of the Ukrainian peasant, defining the essential role of the female principle in the macrocosm - the environment of gods and natural spirits, and in the microcosm of the family, determining the corresponding gender priorities of folk rites.

In Christian and folk traditions, the feast of the Entry (Vvedinnia, Vovedeniie) is associated with the highest deity, who embodies the feminine, maternal principle. According to the Church calendar, December 4 marks the Entry of the Most Holy Theotokos into the Temple to consecrate her to God. In the folk calendar, this is the Earth festival, which continues until the Annunciation day. At this time, the Earth is blessed by God, it wakes up from its winter sleep, awakening all living creatures (Zhaivoronok, 2006, p. 243). M. Hrushevskyi (1993) noted that the period between holidays of the Entry and "Barbara" was the end of the old economic year and the beginning of a new one. This is confirmed by the popular superstitions, for example, after the Entry day it was forbidden to dig the ground, disturb the water: from the Entry day to the ninth Thursday women were not allowed to beat their linen with rolls in the water, because it could damage the field. After the Entry day, it was forbidden to rub hemp, so as not to attract clouds, storms, etc. (p. 174).

From the complex of pre-Christian female rites associated with the Entry day, the rite of blessing of water has been preserved. The peculiar feature of this 
rite is that it was the women who found the place where three rivers or streams were merged, and scooped water with the stream (called "untouched water" by people). After pouring it through the flames, this water was considered "alive" and helped against diseases and evil eyes. According to O. Voropai (1993), the "holy water" of the Entry day in the various areas of the Dnieper Ukraine was used to "attract" a young man to a girl, that is, as a means of maiden magic (p. 11). The ritual of spinning of self-seeding hemp also belonged to the specific rites of the Entry day. It was carried out at midnight: naked women were spinning, sitting on the doorstep. During the day, the women showered the cows with hemp seed, at the same time oiling the udder "to give a lot of milk". On the Entry day, women, especially the old, sick and poor, were wary of visiting relatives and neighbours, since the first visitor - "polaznyk" - was associated in the people's consciousness with a happy or unhappy new year (a young healthy and beautiful man was considered a desirable "polaznyk" (visitor), the most undesirable - an old sick woman). This negative identification of a woman as to prohibitions or undesirability of her presence, is fully explained by $\mathrm{O}$. Kis (2012): "we must not forget that in the era of the World tree that has replaced the era of the Great Mother, with the approval of the basic semantic opposition of male/female tantological and infernal aspects of women's symbols are enhanced: the female loses its sacred and order-making sense, but moving closer to the concept of chaos, darkness, destruction, is placed in one paradigmatic line with death, the afterlife, impurity, threat. This trend is reinforced by the emergence of monotheism, with the spread of which women are gradually displaced from the sacred sphere at the ideological level (the one God is represented as a person) and at the level of performing the religious rituals (the priests are men)" (p. 261).

The feast day of the Great Martyr Katherine of the Church calendar, which was celebrated on the seventh of December, was considered by people as a holiday of maiden fate. Throughout Ukraine it is associated with unmarried girls and young men who tried to discover their fate with a variety of divinations and calls of Fate (which in this case is understood as marriage) (Voropai, 1993, p. 14).

A special role in the winter women's rites is played by the archaic holiday of Kalyta, Christian holiday of Andrew (December 13) and Barbara (December 17). On St. Andrew's night, using various methods of divination, described in sufficient details by ethnographers, girls try to guess not only whether they would get married, but also to identify the main characteristics of the future husband: beloved - unloved, good - bad, good - evil, rich - poor, hard-working - lazy, non-drinker - drunkard, and so on. Special divination is dedicated to those a man or a woman - who will rule in family life, which is the evidence of the dependence of the gender hierarchy not on the established patriarchal rules, but on the personality of men and women in married life. O. Voropai (1993) described the following divination: "Take a rooster and a hen, tie them together with their tails and cover them with a sieve, so that they first calm down. After a while, they release them from under the sieve and watch: who leads. If the rooster pulls the hen - "the husband will be on the top", and if the hen pulls the rooster, then the wife will rule over the husband" (p. 19). V. Skurativskyi (1994) 
also describes the old divination rite, which was preserved in the Polissia region in the form of "the magical sowing" of flax or hemp, when, girls run out into the street, saying:

"Saint Andrew,

I sow hemp on you,

Let me know, God,

Who will take them" (p. 651).

In addition to the reference to "Andrew", it is quite obvious that this ritual of the unmarried girls' divination is connected with the cult of the Earth.

In the context of this study, important is the indirect mention by V. Skurativskyi of an old belief, according to which, "oven bowls", talking between themselves, characterize their owners: the way the housewives take care of them, wash them, do not swear, and so on. Women on the eve of the holiday tried to please bowls -they were washed, solemnly put on white tablecloths, wrapped in hops, made a swill from hops - it was believed that cows, after drinking it, were not afraid of thunder, and predators would be afraid to approach the cows. This rite was especially important for women who had daughters of marriageable age. "They believed that if you neglected this rite, then it would be difficult for their daughters when they got married to give birth" (Skurativskyi, 1994, p. 652). This rite shows a living connection between the housewife and all household utensils: it depended on the housewife's carefulness. However, there was another side: the presence of things and household items seemed to oblige the housewife to adhere to the established norms of behaviour: be neat, agile, do not swear, and so on.

The feast day of St. Barbara was considered as turning point between winter and spring ("Saint Barbara snatched the nights - increased the days"), although, according to M. Hrushevskyi (1993), archaic ceremonies of the New Year's celebrations, which were associated with this day [it should be emphasized - with the female principle. - author's notes], "moved from here mainly to Christmas" (p. 176). On this women's day, young women were forbidden to wash, whiten and knead clay (Voropai, 1993, p. 211).

Winter "feasts" that preceded the Christmas and New Year ended with the feasts of St. Anna (December 22) and Spyrydon solstice (December 25). The feast of St. Anna was on the winter solstice, after which the sun returned to summer. Describing this holiday, V. Skurativskyi (1994) calls it "the families of the sun" (p. 653), which confirms the strong association of the sun with the feminine principle.

The role of women is also important in the complex of the Christmas and New Year rites, which complete the farewell to Winter and honours the birth of the new sun (Christmas - January 7; "Basil" - January 14 and Blessing of water - January 19). Using a wide range of sources, S. Kylymnyk (1994) notes that the preparation for Christmas began long before the holiday itself. The master arranges the macrocosm of the family - makes a complete order in the entire household, performs protective actions - sprinkles a magic potion (poppy), hits the doorstep with an axe to "finish", expel the evil that has settled on the threshold. Then, for the same purpose, the cattle pass this axe in the yard, 
so that all the bad things that stick to their feet or wool can be removed. It is the master who together with his son brings the sheaf of wheat into the house, he is the first to say a prayer to the gods, fumigates the house with smoke and sprinkles Holy water. The housewife ordered and updated the microcosm - home space inside and outside: her duties included buying new dishes, sewing and embroidering new clothes, towels, smearing the house with white clay, painting the fireplace with flowers, domestic and fantastic birds, put potion in the corners of the house.

"Old women plucked feathers and wool and taught children to sing carols in the evenings. The girls wove wreaths and decorated them with duck feathers" (Kylymnyk, 1994, pp. 17-18).

As a whole the actions of the master in the household and his wife in the house are quite complex and time-consuming ritual, the essence of which is the ordering, updating of the peasant microcosm. The sacred meaning of the rites - the preparation of home space in honour of the Goddess, mother was expressed by the ritual potion, among which oregano and Bohorodychna herb (thyme) were necessary. The painting of the stove also has the mythological meaning, not only from the aesthetic side - as a decoration of the home interior, but also as a sacred action to attract the life-giving forces of Mother Earth and protect against hostile forces. "Even in the $18^{\text {th }}$ century, the walls of houses were painted with flowers and various symbolic signs that have remained on the Easter eggs", notes S. Kylymnyk (Kylymnyk, 1994, p. 18). Over time, there was an obvious weakening of the symbolic content of the ritual pre-Christmas paintings, but this rite remained active, explaining "the meaning of those carols that likened a modest house of a peasant to the ordered Cosmos" (Skurativskyi, 1994, p. 35). Thus, the function of ordering the peasant house microcosm is performed by a woman, just as ordering of the macrocosm - by the mother Goddess. "In the house, as in a wreath, she sits like a flower", "The house is beautiful by its housewife" "Women held the house for three corners, a man for one" - folk sayings that characterize the traditional Ukrainian culture (Nomys, 2004, p. 43).

One of the most important duties of a woman was to protect the home, and therefore the family from evil forces, which was reflected in the Christmas rites. So, on the Rich Kutia, Holy supper, when the souls of the dead were gathered in the house, the sheaf of wheat was brought into the house and installed in the corner, the housewife took a "magic potion" (in the $19^{\text {th }}$ and early $20^{\text {th }}$ century, mainly garlic) and pronounced magic words, putting the potion in the four corners: "Evil force, dark force, go to the swamps, reeds, ravines-rocks in deep waters-abyss, where the chicken's voice does not reach, where the sun does not shine" (Kylymnyk, 1994, p. 25). The woman was always close to her husband in those Christmas rites where the leading role belonged to the master - inviting the souls of the dead and natural spirits to dinner, magical actions aimed at ensuring material prosperity, health, and so on.

V. Myloradovych in the work "The life of peasant from Lubensk", describing the process of bringing the water for the preparation of the ritual food, notes: "A woman does not go to bring water on these days early in the morning [that is, on Christmas and New Year holidays. - author's notes]; the first one to bring wa- 
ter should be the master ..." (Ponomarov et al., 1991, p. 186). The participation of the master in the process of bringing "untouched water" confirms its sacred meaning. However, if the master simply brings "untouched water", the housewife follows him to the river or to the well and communicates ritually with the water, earth, or well -dipping the bucket, she says hello: "Good day to you, water Uliana, and to land Tetiana! I congratulate you on this holiday, Happy New Year and Basil's Day! God, bless with your Holy spirit... any time" (village Volchok); "Good day to you, well Roman, and you, water Uliana, and you, land Tetiana! I came to you to take water and call on God for help. As water comes to you from the mountains, from the ravines, from the springs, so that all good things come to me" (village Hunske); "Good day to you, water Uliana, and land Tetiana, and well Prokop! And you, the stars! You have three sisters in heaven: one in the evening, one at midnight, and one in the world. Light up the sky and the earth and purify this water" (village Lytviaky)" (Ponomarov et al., 1991, p. 186). In different regions of Ukraine, there were different formulas for magical namecalling, greetings, requests of women to water, earth, stars, wells, etc., in which the ceremonial role functions of the housewife were realized.

Thus, the rites of the Christmas and New Year cycle show the organic and deep connection of women with the goddesses of Earth and Water. This suggests that the image of a woman in the traditional Ukrainian culture was to a certain extent perceived as the everyday embodiment of these sacred entities that personified the main elements of life.

Among the other ceremonial functions of the housewife was "getting a new fire" before preparing the ritual dishes for the Christmas and New Year holidays. After lighting a "new fire" and using a new kerchief, the housewife began preparing twelve ritual dishes, using the main products of the field and garden, as if giving a "report to the new year for their wealth in the past year" (Voropai, 1993, p. 45). The symbolic meaning of this rite consists in reporting not so much to an abstract new year, but to a very real in the people's consciousness Mother Earth, which was represented as all-fertile.

M. Popovych (2001) states that a woman's place in the home space is near the stove: "Inside the house, - the researcher notes, - there are "better" and "worse" parts. The diagonal "stove - pokuttia" (pokuttia - a corner in the Ukrainian peasant house, located diagonally from the stove; the holiest and the most honourable place in the house. - translator's notes.) contrasts these parts of the house: the best place on the "pokuttia", the women's place - in the area of the stove" (p. 33). However, the division of "female" and "male" places into "worse" and "best" is quite relative in the home space, where the housewife generally dominates. Both places are important in the practical support of the family and the ritual aspect, since the stove in the traditional Ukrainian culture is seen as "a symbol of maternal origin, the inviolability of the family, continuity of life, home, homeland"; the stove "has long been a ritual, a cult, like a family altar, where the gods of the family hearth stay" (Zhaivoronok, 2006, p. 456). The performance of the religious rites near the stove as a kind of home altar is entrusted exclusively to a woman. The process of making the bread, especially ritual, on the occasion of holidays, including the winter cycle, was accompanied 
by the important and complex rites. A number of such rites, associated with many signs and taboos, were described by V. Myloradovych in his work "The life of peasant from Lubensk" (Ponomarov et al., 1991, pp. 189-192).

The microcosm of the family, which consists of three main elements of the family structure - father, mother and children, in carols and songs is identified with the heavenly bodies. The uniqueness of the great magic of the Ukrainian carols and songs is shown not only in the fact that they, along with the master, constantly mention the housewife and her cosmic symbol - the sun. A number of carols are exclusively dedicated to the housewife, who appears in the image of an ideal woman - the personification of a happy family life and all female qualities: beauty, hard work, economy, and so on. "Know who the housewife is:

Her house as a rainbow,

Her servant walks in gold,

Walks in gold, wanders in good..." (Voropai, 1993, p. 66). The heavenly doors of God's house open before such a housewife themselves; God himself holds the service for her and for "the whole house for the health of all". The separate carols are dedicated to female representatives of any age and role in the family hierarchy - a girl and her sister, mother-in-law, grandmother, widows in need.

The phenomenon of girls' carolling and girls' "Malanka" is the proof of gender equality in the traditional Ukrainian society. In contrast to the young men's carolling groups, the girls did not carry a "star", but a lantern that looked like a moon or a star, began carolling when it was quite dark, and that is, after the young men, while not coming into the house. The girls" carolling group had a "birch" - a leader. Describing a "girls' carol”, O. Voropai (1993) captures an important detail: in the text of the carol, the sun-woman is mentioned in the first place:

"...And in that garden there are three towers:

In the first - the red sun,

In the second - a clear moon,

In the third - small stars" (p. 58).

Further in the text of the carol the master is mentioned:

"A clear moon - a master,

Red sun - his wife,

Small stars are his children...” (Voropai, 1993, p. 58). So, it should be noted that the violation of the principle of hierarchy in the girls' carols indicates the optional character of its observation in the Ukrainian ethno-culture.

The girls" "Malanka" has certain differences from the one of young men, in particular, according to O. Voropai, it is characterized by "a more serious character". Besides "Malanka" and "Basil", all the girls from the group are called "druzhky"; the girls' scenario of "Malanka" is marked by less elaboration and, at the same time, restraint in jokes (Voropai, 1993, pp. 100-101). The decisive factor that caused the differences between "Malanka" of the girls and the one of the young men was not so much gender restrictions, but the gender specificity of both groups and the acting abilities of the specific performers.

The girls rented a house for their gatherings, mostly from a single widow or a wife of a soldier, paying for the rent of the house with food. This premarital communication took place under the watchful eye of the owner of the house, 
which symbolized to a certain extent the supreme maternal principle. The "Christmas day" holiday fell on January 13, old style (January 31, new style). Describing it, $\mathrm{O}$. Voropai draws attention to the fact that it was marked by a ban on working and the sanction of the use of vodka. At the same time, the researcher qualifies Christmas day as a joint family holiday (Voropai, 1993, pp. 122-123). O. Boriak in the notes to the article of V. Myloradovych "The life of peasant from Lubensk" also does not highlight the gender peculiarity of the holiday: Christmas day "was considered a transition from a holiday to weekdays. On this day, they still refrained from doing the house work, but gave everyday look to the house, finished with festive meals" (Ponomarov et al., 1991, p. 591). The true meaning of Christmas day in the folk calendar was revealed by V. Myloradovych. His description of this holiday gives grounds to attribute it as feminine.

According to V. Myloradovych, the main ritual action of Christmas day was the "bringing in of the spinning comb" - a symbol of Mokosh and women's work. On Christmas and New Year's holidays, the spinning comb was taken to the barn "so that the holidays could last". In the ritual of turning of the spinning comb into a symbol of a female deity, most likely of Mokosh, the motif of belief in the magical healing by things that were sacralised and thus acquired healing properties can clearly be traced. "Christmas day" and other women's holidays, where visiting of the pubs as traditional places of public gatherings was a part of the ritual, indicate a high degree of women's independence in the traditional Ukrainian society. The prevalence of the custom of the ritual collective meals with only women present indicates a considerable number of recorded by folklorists comic women's "drunken" or "tavern" songs, including those presented in the work of V. Myloradovych (Ponomarov et al., 1991, pp. 196-200).

Thus, the analysis of gender aspects of the Ukrainian winter calendar rites allows us to question the traditional for the ethnographic sources statement that the leading role in the rites of the winter cycle belongs to a man. This statement was made, in particular, by M. Hrushevskyi (1993), describing the insignificant, in his opinion, influence of Christian ideology on Christmas celebrations: "Christian ceremonies play quite a secondary role compared to a number of rites performed by the head of the family, the master, and partly the housewife" (p. 177). However, it is better to speak about the parity of male and female roles in the implementation of the main idea of winter rites, which is: "by word and deed, verbal work and magic acts, the whole situation to create the image of wealth, happiness, peace and calm in your home at this festive moment and thus enchant this wealth and happiness for a whole year, in this secret moment” (Grushevsky, 1993, pp.177-178).

\section{Conclusions}

The cult of the earth, Mother Earth, Mother Water and agricultural work, which is the basis of the ideology of the Ukrainian peasant, defines the essential role of the feminine principle both in the macrocosm - environment of gods and elemental spirits, and in the microcosm of the family, determining the corresponding gender priorities of the rituals. It has been defined that the 
role of a women in the winter rites differs from the role of a man in its symbolic content, but it is devoid of any signs of hierarchical subordination, rigidly fixed subordination, secondary importance. Sometimes, even the opposite - it is the leading one, which is explained by the mythological content of Christmas and New Year rites as those that are addressed directly to the highest female deity (Mother-earth, Mother-water) and indicate the organic and deep connection of a woman with the goddesses of Earth and Water. This suggests that the image of a woman in the traditional Ukrainian culture was to a certain extent perceived as the everyday embodiment of these sacred entities that personified the main elements of life. The gender hierarchy of the traditional Ukrainian family mainly depends not so much on the established patriarchal rules, but on the personality and social status of men and women in married life. In general, the gender identity of the Ukrainian rites of the winter calendar cycle consists in the parity of female and male roles, which symbolizes the harmony in the family microcosm and the macrocosm of the environment. The leitmotif of these rites was a call for the universal harmony at the macro and micro levels.

The results of this study complement the systematic research on the status of the Ukrainian women in the traditional culture, demonstrate the complexity and versatility of the issue, which requires in-depth emphasis and disclosure in the question of women's role in the game component of the rite.

\section{References}

Antonovych, D. (Ed.). (1993). Ukrainska kultura [Ukrainian culture]. Lybid [in Ukrainian]. Hromova, N. (2012). Rol zhinky v ukrainskii kalendarnii obriadovosti [The role of women in the Ukrainian calendar rituals]. In M. Hrymych (Ed.), Narodna kultura ukraintsiv: zhyttievyi tsykl liudyny: istoryko-etnolohichne doslidzhennia [Folk culture of Ukrainians: human life cycle: historical and ethnological research] (Vol. 3: Zrilist. Zhinotstvo. Zhinocha subkultura [Maturity. Femininity. Female subculture]). Duliby [in Ukrainian].

Hrushevska, K. (2012). Z prymityvnoho hospodarstva. Kilka zauvazhen pro zasoby zhinochoi hospodarchoi mahii u zviazku z naistarishymy formamy zhinochoho hospodarstva [From primitive economy. Some observations on the means of feminine household magic in relation to the oldest forms of female housekeeping]. In M. Hrymych (Ed.), Narodna kultura ukraintsiv: zhyttievyi tsykl liudyny [Folk culture of Ukrainians: human life cycle] (Vol. 3: Zrilist. Zhinotstvo. Zhinocha subkultura [Maturity. Femininity. Female subculture]). Duliby [in Ukrainian].

Hrushevskyi, M. (1993). Istoriia ukrainskoi literatury [History of Ukrainian literature] (Pt. 9, Vol. 1). Lybid [in Ukrainian].

Hrymych, M. (2012). Zhinoche mainove pravo u tradytsiinomu ukrainskomu suspilstvi [Women's property law in traditional Ukrainian society]. Duliby [in Ukrainian].

Kis, O. (2012). Zhinoche nachalo $\mathrm{v}$ narodnomu svitohliadi ta tradytsiinyi stereotyp feminnosti [Female origin in the folk worldview and the traditional stereotype of femininity]. In M. Hrymych (Ed.), Narodna kultura ukraintsiv: zhyttievyi tsykl liudyny [Folk culture of Ukrainians: human life cycle] (Vol. 3: Zrilist. Zhinotstvo. Zhinocha subkultura [Maturity. Femininity. Female subculture]). Duliby [in Ukrainian]. 
Kostomarov, M. (2014). Slovianska mifolohiia [Slavic mythology]. Stebeliak [in Ukrainian]. Kurochkin, O. (2014). Sviatkovyi rik ukraintsiv: vid davnyny do suchasnosti [Festive year of Ukrainians: from ancient times to the present]. O. V. Pshonkivskyi Publishing House [in Ukrainian].

Kylymnyk, S. (1994). Ukrainskyi rik u narodnykh zvychaiakh $v$ istorychnomu osvitlenni [Ukrainian year in folk customs in historical light] (Pt. 2). Oberehy [in Ukrainian].

Maksymovych, M. (2002). Dni ta misiatsi ukrainskoho selianyna [Days and months of the Ukrainian peasant]. Oberehy [in Ukrainian].

Meletinskii, E. M.(Ed.).(1991).Mifologicheskii slovar [Mythological dictionary]. Sovetskaia entciklopediia [in Russian].

Myshanych, O. V. (Ed.). (1989). Litopys ruskyi (Ipatskyi litopys) [Russian Chronicle (Ipat Chronicle)] (L. Ye. Makhnovyts, Trans.). Dnipro [in Ukrainian].

Nomys, M. (Comp.). (2004). Ukrainski prykazky, pryslivia [Ukrainian proverbs, sayings]. Lybid [in Ukrainian].

Ponomarov, A. P., Kosmina, T. V., \& Boriak, O. O. (Comps.). (1991). Ukraintsi: narodni viruvannia, obriady, demonolohiia [Ukrainians: folk beliefs, rituals, demonology]. Lybid [in Ukrainian].

Popovych, M. (2001). Narys istorii kultury Ukrainy [Essay on the history of Ukrainian culture] (2nd ed.). ArtEk [in Ukrainian].

Skurativskyi, V. T. (1987). Berehynia [Berehynia]. Radianskyi pysmennyk [in Ukrainian].

Skurativskyi, V. T. (1994). Sviatvechir [Christmas Eve] (Pt. 2: Ukraintsi [Ukrainians]). Perlyna [in Ukrainian].

Voitovych, V. M. (2005). Ukrainska mifolohiia [Ukrainian mythology] (2nd ed.). Lybid [in Ukrainian].

Voropai, O. (1993). Zvychai nashoho narodu: etnohrafichnyi narys [Customs of our people: ethnographic essay]. Oberih [in Ukrainian].

Zhaivoronok, V.V. (2006). Znaky ukrainskoi etnokultury: slovnyk-dovidnyk [Signs of Ukrainian ethnoculture: dictionary-reference book]. Dovira [in Ukrainian].

Zhulynskyi, M. (Ed.). (2003). Istoriia ukrainskoi kultury [History of Ukrainian culture] (Vol. 3: Kultura ta rozvytok nauky i tekhnolohii v Ukraini [Culture and development of science and technology in Ukraine]). Naukova dumka [in Ukrainian].

\title{
ЖІНКА В УКРАЇНСЬКИХ ОБРЯДАХ ЗИМОВОГО КАЛЕНДАРНОГО ЦИКЛУ
}

\author{
Линюк Олена Миколаївна
}

Кандидат культурології, доцент, ORCID:0000-0003-0665-9589,partyzone5@ukr.net, Київська муніципальна академія естрадного та циркового мистецтва, Київ, Україна

Мета статті полягає у виявленні гендерних пріоритетів (паритетності чоловічих та жіночих ролей) в українських обрядах зимового календарного циклу на основі 
аналізу міфологічних витоків системи обрядовості та складу обрядів, головна роль у виконанні яких належала жінці. Для досягнення мети було застосовано методи: узагальнюючий - для систематизації наукових джерел; аналітичний метод - для аналізу причинно-наслідкових особливостей, виникнення і становлення тенденцій у комплексному дослідженні наукових проблем; метод ретроспективної реконструкції або історико-генетичний метод, в основі якого лежить ідея про те, що початкові етапи розвитку певних об’єктів і явищ можна відтворити на підставі пізніших етапів. Наукова новизна дослідження полягає у аналізі специфіки розподілу жіночих та чоловічих ролей, виявленні та обгрунтуванні особливої ролі жінки та акцентуванні гендерних пріоритетів в обрядах зимового календарного циклу. Висновки. Встановлено, що культ Матері-землі і Матері-води визначає істотну роль жіночого начала як у макрокосмі середовищі богів і духів, так і в мікрокосмі родини, зумовивши відповідні гендерні домінанти обрядовості. З’ясовано, що роль жінки в зимовій обрядовості має відмінне від ролі чоловіка символічне наповнення, однак позбавлена прикмет ієрархічної підлеглості, другорядності. В ряді моментів навпаки - $є$ провідною, що пояснюється міфологічним змістом різдвяно-новорічних обрядодійств як таких, що звернені безпосередньо до вищого жіночого і засвідчують органічний і глибинний зв’язок жінки з богинями Землі і Води. Це дозволяє припустити, що образ жінки у традиційній українській культурі сприймався як побутове втілення цих сакральних сутностей і $є$ підтвердженням спорідненості ритуалу і міфу. Виявлено, що віра у верховенство жіночого божества трансформувалася під впливом християнства. Доведено, що гендерна ієрархія традиційної української родини переважно залежить не стільки від усталених патріархальних правил, а від особливостей характеру та соціального стану. Гендерна своєрідність обрядів зимового календарного циклу полягає у паритетності жіночих і чоловічих ролей, що символізує гармонію у родинному мікрокосмі і макрокосмі оточуючого середовища.

Ключові слова: міфологія; народний календар; Матір-вода; Матір-земля; Мокоша; мікро- та макрокосмос; паритетність.

\section{ЖЕНЩИНА В УКРАИНСКИХ ОБРЯДАХ ЗИМНЕГО КАЛЕНДАРНОГО ЦИКЛА}

\section{Линюк Елена Николаевна}

Кандидат культурологии, доцент, ORCID: 0000-0003-0665-9589, partyzone5@ukr.net, Киевская муниципальная академия эстрадного и циикового искусства, Киев, Украина

Цель статьи заключается в выявлении гендерных приоритетов (паритетности мужских и женских ролей) в украинских обрядах зимнего календарного цикла на основе анализа мифологических истоков системы обрядности и состава обрядов, главная роль в выполнении которых принадлежала женщине. Для достижения цели были применены методы: обобщающий - для систематизации научных источников; аналитический метод - для анализа причинно-следственных особенностей, 
возникновения и становления тенденций в комплексном исследовании научных проблем; метод ретроспективной реконструкции или историко-генетический метод заключается в том, что начальные этапы развития определенных объектов и явлений можно воспроизвести на основании более поздних этапов. Научная новизна исследования заключается в анализе специфики распределения женских и мужских ролей, выявлении и обосновании особой роли женщины и акцентировании гендерных приоритетов в обрядах зимнего календарного цикла. Выводы. Установлено, что культ Матери-земли и Матери-воды определяет существенную роль женского начала как в макрокосме - среде богов и духов, так и в микрокосме семьи, обусловив соответствующие гендерные доминанты обрядности. Выяснено, что роль женщины в зимней обрядности имеет отличное от роли мужчины символическое наполнение, однако лишена примет иерархической подчиненности, второстепенности. В ряде моментов наоборот - является ведущей, что объясняется мифологическим содержанием рождественско-новогодних обрядов как таковых, которые обращены непосредственно к высшим женским божествам и демонстрируют органическую и глубинную связь женщины с богинями Земли и Воды. Это позволяет предположить, что образ женщины в традиционной украинской культуре воспринимался как бытовое воплощение этих сакральных сущностей и является подтверждением родства ритуала и мифа. Выявлено, что вера в верховенство женского божества трансформировалась под влиянием христианства. Доказано, что гендерная иерархия в традиционной украинской семье в основном зависит не столько от устоявшихся патриархальных правил, а от особенностей характера и социального положения мужчины и женщины. Гендерное своеобразие обрядов зимнего календарного цикла заключается в паритетности женских и мужских ролей, символизирующей гармонию в семейном микрокосме и макрокосме окружающей среды.

Ключевые слова: мифология; народный календарь; Мать-вода; Мать-земля; Мокошь; микро- и макрокосмос; паритетность. 